\title{
Recerca i formació de professionals en el camp de la literatura infantil $i$ juvenil $\mid$ Research and training of professionals in the field of children's and young adult literature
}

\author{
Teresa Colomer \\ Universitat Autònoma de Barcelona
}

(Text rebut el 20 de març de 2018; acceptat el 30 de març de 2018)

DOI: http://doi.org/10.5565/rev/jt13.762

Resum: El 2017, Catalunya i les Illes Balears van ser convidades a celebrar la 54 edició de la Fira del Llibre per a Infants i Joves de Bolonya. El programa incloïa el Simposi sobre literatura infantil i juvenil en català: tendències d'un futur compartit. Aquest és el text de la conferència impartida per la Dra. Teresa Colomer com a part del Simposi, en la seva versió original en català i la traducció a l'anglès de l'Institut Ramon Llull. Les diapositives de la conferència es poden consultar al següent enllaç: http://www.gretel.cat/publicacions/research-and-training/

Paraules clau: Literatura infantil i juvenil, àrea de parla catalana, recerca, formació

\begin{abstract}
In 2017, Catalonia and the Balearic Islands were invited as guests of honour at 54th edition of the Bologna Children's Book Fair. The program of the Fair included the Symposium on Children's and Young Adult Literature in Catalan: Trends for a Shared Future. This text reproduces the conference given by Dr. Teresa Colomer as part of the Symposium, both in the Catalan original, and translated into English by the Institut Ramon Llull. The slides of the presentation may be consulted by following this link: http://www.gretel.cat/publicacions/research-and-training/
\end{abstract}

Keywords: Children's and young adult literature, Catalan-speaking area, research, training

Resumen: En el año 2017, Cataluña y las Islas Baleares fueron invitados de honor en la $54^{\mathrm{a}}$ edición de la Feria del Libro Infantil y Juvenil en Bolonia. El programa incluyó el Simposio sobre literatura infantil y juvenil en catalán: tendencias de un futuro compartido. En este texto se reproduce la conferencia impartida por la Dra. Teresa Colomer como parte del Simposio, tanto en su versión original en catalán, como la traducción al inglés realizada por parte del Instituto Ramon Llull. Las diapositivas de la conferencia se pueden consultar en el enlace siguiente: http://www.gretel.cat/publicacions/research-and-training/

Palabras clave: Literatura infantil y juvenil, área de habla catalana, investigación, formación

\section{Introducció}

La meva exposició s'adreça a presentar la recerca i l'oferta formativa que aporta l'àrea de parla catalana "al concert de les nacions". Els intentaré convèncer, amb uns pocs exemples, que l'àrea catalana ha estat pionera en molts camps i s'ha situat com un focus internacional 
d'interès en investigació i formació universitària. Ho faré a partir de tres moments diferenciats: els inicis dels estudis a finals de la dictadura franquista, la constitució de la recerca universitària al tombant del segle XXI i els canvis de la darrera dècada amb la internacionalització de la recerca i l'expansió de l'oferta formativa.

\section{Els inicis de la recerca i formació}

En la majoria de països els estudis han nascut a partir de la preocupació per seleccionar bon llibres i posar-los en mans dels infants. És una preocupació ben pròpia del sector bibliotecari, de manera que és allà on es desenvolupa la reflexió a mesura que els països creen biblioteques infantils, des de finals del segle XIX fins al període d'entreguerres del segle XX. A l'àrea catalana ho trobem així mateix i ben aviat. Ja al 1908 l'Ajuntament de Barcelona debatia la necessitat de dotar de secció infantil a les biblioteques, al 1915 es fundava la primera Escola de Bibliotecàries d'Europa, al 1918 la Mancomunitat de Catalunya creava les tres primeres biblioteques amb secció infantil d'Espanya i al 1921 s'organitzaven biblioteques escolars circulants per a les escoles municipals de Barcelona.

A partir de la Segona Guerra Mundial, el moviment bibliotecari s'amplia arreu a través d'organismes internacionals i comença la seva col·laboració amb l'àmbit educatiu, que s'obria als llibres "extraescolars” i feia seva la preocupació per la selecció. També a l'àrea catalana dels anys 60 s sorgiren els moviments de renovació pedagògica, tot prenent com a model els moviments pedagògics francesos, que preconitzaven la lectura a través dels llibres infantils i juvenils, de manera que ja al 1964 es publicava la primera selecció de llibres per part del que es convertiria en el Seminari de bibliografia infantil i juvenil de l'Associació de Mestres Rosa Sensat. Les relacions amb les institucions internacionals es produïren amb el restabliment democràtic. Al 1982 es van constituir alhora el Consell Català del Llibre Infantil i Juvenil (ClijCAT) i l'Organización Española para el Libro Infantil y Juvenil (OEPLI), un organisme necessari per constituir-se com a secció espanyola de la International Board on Books for Young People (IBBY) i que va adoptar una forma federal d'organització entre les quatre llengües de l'Estat.

Un segon tipus de reflexió no es proposa saber què fer dels llibres, sinó descriure'ls. S'aborda així la delimitació d'obres i autors, tot establint la història d'aquesta literatura a partir del moment en què hi ha un gruix suficient de producció i de temps que permet fer-ho. A l'àrea catalana els primers estudis històrics provenen encara del sector bibliotecari, amb la particularitat que aquí la descripció neix des de la perspectiva de la memòria, des de la necessitat de consignar detalladament l'esforç realitzat per tal de mantenir la idea d'una cultura on entroncar-se després de la desfeta. Destaquem l'obra de Teresa Rovira, que establí amb detall rigorós la història del llibres infantils del primer terç del segle (1968, 1976), així com 
els repertoris bibliogràfics dels llibres infantils i juvenils catalans (Ventura,1970; Rovira i Carmé Ribé, 1972), que foren els primers d'Espanya.

Un tercer tipus de reflexió, molt extensa internacionalment, debat què són aquests llibres a cavall entre l'art i l'educació, amb grans polèmiques sobre la seva relació amb "la literatura" sense adjectius o sobre la sospitosa qualitat formativa de la fantasia i el folklore. La discussió sobre les "essències" literàries de la literatura infantil, tingué molt pocs adeptes a l'àrea catalana. El fet que els llibres per a infants s'haguessin contemplat sempre com un instrument decisiu per a l'èxit d'un projecte cultural propi va deixar pragmàticament fora de lloc aquesta discussió. I l'interès pel folklore i la fantasia va viure hores baixes a casa nostra. D'una banda la dictadura franquista exaltava un folklore comú al servei d'una cultura espanyola única. D'una altra, l'anhel català d'adherir-se als aires culturals europeus provocava la recança cap a la fantasia pròpia de la pedagogia racionalista que dominava als països occidentals.

Però el gir internacional cap a la fantasia coincidí amb l'arribada de la democràcia. Encara en el predemocràtic any 1976 l'editorial catalana Avance publicava la primera traducció a Espanya de la Gramática de la fantasía, de Gianni Rodari i llavors l'àrea catalana s'hi apuntà amb entusiasme, perquè confluien el desig de mantenir-se en la modernitat europea amb la recuperació de la tradició oral com a cultura pròpia. L'obra de Gabriel Janer Manila va ser capdavantera $i$ punt de referència en aquest àmbit $i$, sota el seu mestratge, el nucli universitari de les Illes Balears va fer especial atenció als estudis sobre folklore, fantasia i literatura infantil.

\section{La constitució de la recerca universitària al tombant del segle XXI}

Durant les dècades dels anys 80 s i 90s la literatura infantil i juvenil va anar guanyat terreny com objecte d'estudi acadèmic. L'editorial Pirene va formar en català la primera col·lecció d'estudis d'Espanya, amb traduccions i estudis propis, mentre que la formació en literatura infantil i juvenil s'estenia per les titulacions universitàries, especialment les educatives. Així que els departaments universitaris es van fer càrrec d'aquesta nova àrea en construcció.

Al final de la dècada dels noranta, els investigadors catalans van formar la primera xarxa de recerca universitària de l'Estat espanyol. Una dada important, que revela un salt en el desenvolupament dels nostres estudis. Amb el títol de Xarxa temàtica de teoria, història $i$ ús educatiu de la literatura infantil i juvenil catalana (1999-2006) i coordinada per Teresa Colomer, va agrupar tots els investigadors de les universitats d'Alacant, Autònoma de Barcelona, Barcelona, les Illes Balears, Rovira i Virgili, València i Vic. Ens va deixar dues publicacions adreçades als fonaments dels nostres estudis: 
L'una tracta de la base de la nostra literatura. El patrimoni de la imaginació: llibres d'ahir per a lectors d'avui va ser coordinada per Mònica Baró, Teresa Colomer i Teresa Mañà i editada al 2007 a Palma per obra de Gabriel Janer Manila, director en aquells moments de l'Institut d'Estudis Baleàrics. Com el seu títol vol indicar, es proposava recuperar i difondre les obres que configuren la nostra tradició literària.

L'altra tracta de la base dels nostres estudis. La literatura infantil i juvenil catalana: un segle de canvis va ser coordinada per Teresa Colomer i publicada al 2002 per l'ICE de la $\mathrm{UAB}^{\mathrm{i}}$. Es proposava establir el mapa dels canvis socials $\mathrm{i}$ culturals que havien condicionat el desenvolupament de la producció durant el segle XX, així com dels estudis catalans que s'havien adreçat específicament a cadascun d'aquests camps ${ }^{\mathrm{ii}}$.

Respecte aquests centres d'interès, les obres clau d'aquest període es poden dividir en tres grups: el primer amb l'ampliació dels estudis del folklore i la història (amb autors com Janer Manila, Valriu o Castillo). El segon grup amb obres que van adoptar temes i enfocaments propis dels estudis literaris i artístics de la segona meitat del segle XX, amb la nova consideració cap al lector, i els van fer confluir amb la nova atenció cap a l'aprenent de les disciplines educatives. L'adopció d'aquestes perspectives, amb la introducció de la influència anglosaxona que se superposà a la francesa, va suposar un salt qualitatiu de modernització dels estudis (Colomer, Duran, Lluch o Mendoza). En tercer lloc podem agrupar altres perspectives, com la ideològica (Bassa, Obiols), la relacionada amb d'edat del destinatari (Duran i Ros) o el primer informe existent a Espanya sobre biblioteques escolars (Baró, Mañà i Roig), com a mostra del progrés també en la variació i amplitud temàtica.

\section{La recerca a la darrera dècada}

Un cop integrats els estudis de literatura infantil i juvenil a les universitats, la seva evolució segueix els camins generals del sistema universitari als països occidentals. El seu tret més característic és la configuració de grups de recerca estables: BESCOLAR, sobre biblioteca escolar, dirigit per Teresa Mañà a la UB; FRAC, Grup de recerca de formació receptora i anàlisi de competències, dirigit durant molt de temps per Antonio Mendoza i actualment per Margarida Prats, a la UB; GREIB, Grup de recerca en etnopoètica de les Illes Balears, dirigit per Caterina Valriu de la UIB i GRETEL, Grup de recerca d'educació literària i literatura infantil i juvenil, dirigit per Teresa Colomer a la UAB.

Una segona característica és la internacionalització de la recerca. És aquí on podem afirmar que l'àrea catalana s'ha constituït com un focus potent d'investigació en el mapa internacional. En citarem tres aspectes:

1. El contacte especialment intens dels nostres investigadors amb altres universitat $\mathrm{i}$ institucions espanyoles, amb Llatinoamèrica i amb la Comunitat Europea. A tall 
d'exemple, podem destacar la participació en recerques internacionals, com la de Gemma Lluch amb Fundalectura de Colombia sobre criteris de selecció, o la de Teresa Colomer i l'equip GRETEL amb les universitats de Glasgow, Sidney i Columbia sobre recepció i contextos migratoris, que ha estat premiada internacionalment en la seva publicació.

2. La creació de la European Network of Picturebook Research al Simposi de la Universitat Autònoma de Barcelona de 2007, organitzat per Teresa Colomer, Bettina Kümmerling-Meibauer i M.Cecilia Silva-Díaz. El simposi va agrupar els especialistes mundials de més prestigi en el camp de l'àlbum, ha tingut continuïtat en simposis bianuals (a Glasgow, Tübingen, Estocolm, Gdansk i Pàdua aquest 2017) i va propiciar publicacions internacionals.

3. Els intercanvis i l'atracció d'investigadors a les nostres universitats en estades de recerca, realització de tesis doctorals, etc. Per donar una dada il·lustrativa, i em perdonaran perquè recorri a l'única que conec amb detall, el grup de recerca GRETEL ha atès, només aquest curs, setze investigadors visitants d'onze països en estades de duració variable entre setmanes i mesos.

Pel que fa als camps d'interès d'aquesta darrera dècada, cal remarcar, en primer lloc, algunes obres d'abast general o que profunditzen en els eixos històrics, així com la tasca de recerca a través d'exposicions, empeses sovint per aniversaris o commemoracions, algunes sota la direcció de Teresa Duran. En segon lloc, les obres adreçades a la lectura juvenil, especialment a partir de la preocupació social pels hàbits de lectura $\mathrm{i}$ el pas dels joves a les pantalles. En tercer lloc, la línia d'anàlisi literària i de recepció lectora que ha derivat cap a l'interès pels formats digitals en recerques molt pioneres. A noms ja habituals, com Colomer, Díaz-Plaja, Lluch, Manresa, Mendoza, Prats i Valriu, podem afegir les recents investigacions sobre recepció, il·lustració i literatura digital d'Amat, Bellorín, Bosch, Ramada, Reyes o Turrión. La consulta al llistat d'articles sobre literatura infantil i juvenil catalana distingits amb el "Premi Aurora Díaz-Plaja" de l'AELLC, en quinze edicions impulsades per Pere Martí, també dona indicis dels temes que han concitat més atenció, com el terç dels articles premiats dedicats a la poesia infantil catalana.

\section{L'oferta formativa}

El pas a nivell internacional de les universitats cap a una estructura de graus i postgraus ha fomentat l'extensió de l'oferta formativa. En el cas específic de la literatura infantil i juvenil, l'àrea catalana ha esdevingut un focus mundial potent de formació d'investigadors i professionals de tots els sectors implicats. En podem destacar les següents fites: 
Al curs 2004-2005 naixia el Màster online en Llibres $i$ literatura infantil $i$ juvenil organitzat per la UAB en col·laboració amb el Banco del Libro de Veneçuela i coordinat per Teresa Colomer i M ${ }^{\text {a }}$ Cecilia Silva-Díaz. Nascut amb una forta empremta internacional, les seves 10 edicions han acollit més de 400 alumnes procedents de 25 països i el seu equip de professorat ha estat format per més de 130 professionals de 20 països diferents.

Al curs 2008-2009 s'oferia el Màster interuniversitari en Biblioteca escolar i promoció de la lectura (UAB-UB), organitzat per Mònica Baró, Teresa Mañà i Teresa Colomer. Va ser el primer màster oficial sobre biblioteca escolar a Espanya, continua essent l'únic fins ara i el seu èxit va traspassar fronteres, de manera que ha estat pres com a model d'altres ofertes formatives o se li ha encarregat l'organització de cursos específics per part d'instàncies internacionals.

L'oferta s'ha anat ampliant amb l'organització diversificada de cursos universitaris, situats entre els 10 i 30 crèdits docents. Entre els existents en l'actualitat podem assenyalar, per ordre d'antiguitat: el Curs de llibres infantils i juvenils: producció, ús i recepció de la UAB; el Diploma virtual de cultura, lectura i literatura per a infants $i$ joves de la UV; el Diploma de llibreria de la UB i el Gremi de Llibreters de Catalunya; el Children's Books from a Global Perspective de la UAB, així com el recent Curs de Prescripció lectora de la UB. També podem afegir l'existència d'activitats periòdiques estables, com l'Escola d'estiu de literatura infantil $i$ juvenil de la UVic i la UCC, en col-laboració amb l'Abadia de Montserrat o bé els cursos de les Escoles d'estiu de Rosa Sensat i altres llocs del territori.

Destaquem separadament la llarga tradició catalana d'oferta formativa en il·lustració, un fet especialment potent en el nou context d'interès per la imatge: el Màster en il·lustració $i$ còmic, de l'escola ELISAVA i la UPF; el Màster en il-lustració creativa, que inclou els postgraus d'Il·lustració, d'Il·lustració digital i Nous mitjans, del BAU, UVic i UCC; el Màster en disseny i il·lustració de la UPV; el Diplomat d'il.lustració creativa i tècniques de comunicació visual de l'Escola EINA i la UAB; els Cicles formatius de grau superior de l'Escola Massana i la UAB, de la Llotja de Barcelona i de l'Escola Illa de Sabadell o el Curs d'especialització en il-lustració per a publicacions infantils i juvenils de 1'Escola EINA i la $\mathrm{UAB}$.

La literatura infantil i juvenil no ha estat aliena tampoc al moviment de formació virtual en obert, desenvolupat internacionalment en els darrers anys. Ha trencat el gel el curs “Triar llibres per a infants i joves" encarregat per l'IOC, al grup GRETEL de la UAB, coordinat per Mireia Manresa. ${ }^{\text {iii }}$

Tancarem la referència a l'oferta formativa catalana amb un projecte futur de gran abast. S'ha sol·licitat per primera vegada un Erasmus Mundus Joint Master Degree (EMJMD) de literatura infantil i juvenil a la Comunitat Europea. El projecte de l'International Master 
Children's Literature, Childhood Culture and Media, coordinat per Evelyn Arizpe, de la Universitat de Glasgow, agrupa les universitats europees que s'han considerat amb focus més actius de recerca i formació: Aarhus, Autònoma de Barcelona i Tilburg, més la British Columbia de Canadà, amb la col·laboració d'altres cinquanta entitats d'arreu del món, com la Internationale Jugendbibliothek de Munich. La demanda a la UAB inclou la possible assumpció de la coordinació europea del màster, si el Brexit fa impossible la coordinació de Glasgow.

\section{La crítica i altres institucions}

Tot i que aquesta exposició s'ha centrat en la recerca i formació en literatura infantil i juvenil catalana generada per les universitats, afortunadament "hi ha vida més enllà" a través d'un teixit d'organismes i entitats professionals amb una gran ebullició d'activitats de crítica i difusió.

Esmentarem només algunes de les entitats, i de ben diferents, que propicien la recerca i difusió, començant per l'Institut Ramon Llull que organitza aquesta trobada i que manté una línia de subvencions per a la promoció exterior d'editorials i il·lustradors; l'Associació de Mestres Rosa Sensat, on conflueixen grups i iniciatives al voltant dels llibres; el ClijCAT, del qual cal destacar dos interessants estudis sobre hàbits de lectura dels infants i joves (2005, 2010); el Programa de biblioteca escolar puntedu de la Generalitat de Catalunya que va donar nou impuls a les biblioteques escolars; l'Observatori de biblioteques, llibres i lectura de la UB que publica anualment un Anuari en línia amb informes sectorials de gran interès per prendre el pols als diferents vessants del llibre infantil i juvenil ${ }^{\mathrm{iv}}$; l'Associació d'Escriptors en Llengua Catalana (AELLC) que ha permès l'organització de cinc congressos de literatura infantil i juvenil catalana; la Fundació Jordi Sierra i Fabra, amb seus a Medellín i Barcelona; la Fundació Jaume Bofill, amb programes de recerca i suport a la lectura; el Centre de documentació de literatura infantil $i$ juvenil, radicat a la Biblioteca Xavier Benguerel de Barcelona o la desapareguda revista Ooohéee. Estudis sobre la creació i edició infantil i juvenil de l'Institut d'Estudis Baleàrics, publicada en tres llengües, dos exemples, aquests darrers, de l'intent de creació de les infraestructures necessàries per a la investigació i la difusió.

Pel que fa a la crítica especialitzada, compta amb revistes de llarga durada i una notable activitat en formats digitals. En paper, cal citar la revista Faristol del ClijCAT, ara també en versió digital, així com la revista CLIJ, Cuadernos de literatura infantil y juvenil. La web de l'administració educativa de Catalunya acull en digital la selecció per edats del Seminari de Bibliografia de Rosa Sensat i comptem amb un ventall ampli de webs d'especialistes, com la veterana Cornabou, amb la seva hemeroteca La Saloquia, Llibres al 
replà, Mascaró de proa o La invitació a la lectura; mentre que Boolino ha assajat un web de caire més familiar i comercial i el grup GRETEL inclou recomanacions mensuals de obres impreses i digitals, així com una base de dades que mostra les vint obres per a cada bloc d'edat que han estat més recomanades per la crítica des de l'any 2000 a partir del buidat permanent de més de 15 fonts bibliogràfiques especialitzades.

Per tancar aquesta exposició, citaré un fet particular de Barcelona, però que resulta representatiu de l'interès pels llibres, la coordinació d'esforços de tots els sectors, l'apertura al món i les possibilitats de futur que hem volgut mostrar en aquesta intervenció des de l'àmbit que ens ocupa: al 2016 Barcelona va ser nomenada per la UNESCO membre de la "Xarxa de Ciutats Literàries". Els llibres infantils i juvenils van ser presents en els mèrits descrits per la ciutat en la seva candidatura en un article de Teresa Colomer. L'actiu procés de participació dels diferents sectors implicats va donar lloc, tant al recull de la nostra situació per explicarnos al món, com a la possibilitat de somiar-nos millors i amb més capacitats. Desitgem que, avui, l'ocasió que ens ha brindat la Fira de Bolonya contribueixi també a conèixer-nos millor entre tots i a imaginar junts nous camins de progrés per a l'accés de les noves generacions als llibres i la literatura que els esperen.

\section{Introduction}

My presentation focuses on the research and training offer provided by the Catalan-speaking area 'to the concert of nations'. Using a few examples I will show that the Catalan-speaking area has been a pioneer in many spheres and has established itself as an international centre of interest in research and university training. This will be based around three different moments: the beginnings of the studies at the end of the Franco dictatorship, the setting up of university research at the turn of the 21 st century and the changes of the last decade with the internationalization of the research and expansion of training.

\section{The beginnings of the research and training}

In most countries these studies arose from the interest in choosing good books and putting them in children's hands. This is a very characteristic interest of the library sector, which is where reflection developed as countries created children's libraries from the late 19th century to the interwar period of the 20th century. This was so early on in the Catalan-speaking area. The Barcelona City Council was already discussing the need to provide children's sections in libraries in 1908, in 1915 the first school of librarians in Europe was founded, in 1918 the Commonwealth of Catalonia created the first three libraries with children's sections in Spain and in 1921 travelling school libraries were organized for the municipal schools of Barcelona. 
After World War II, the library movement expanded all over through international organizations and it began its collaboration with the educational sphere, which opened itself up to 'extracurricular' books and took charge of the selection. Movements for educational reform also emerged in the Catalan-speaking area in the 1960s, taking as a model the French educational movements that advocated reading through children's and young adult literature. The first selection of books was published in 1964 by what would become the Children's and Young Adult Literature Seminar of the Rosa Sensat Teachers Association. Relations with international institutions were established with the restoration of democracy. In 1982 both the Catalan Council for Children's and Young Adults' Books (ClijCAT) and the Spanish Organization for Children's and Young Adults' Books (OEPLI) were established. The latter organization was necessary for setting up a Spanish section of the International Board on Books for Young People (IBBY), and it adopted a federal form of organization among Spain's four languages.

A second type of reflection proposed not knowing what to do with books but describing them. The delimitation of works and authors was thus addressed, establishing the history of this literature from the moment in which there was a sufficient amount of production and time to do so. The first historical studies in the Catalan-speaking area still came from the library sector, with the particularity that here the description arose from the perspective of memory, from the need to keep a detailed record of the efforts made to maintain the idea of a culture to find roots in following the defeat. Of note is the work of Teresa Rovira, who established with rigorous detail the history of children's books in the first third of the century $(1968,1976)$ and made catalogues of Catalan children's and young adult books (Ventura, 1970; Rovira and Carme Ribé, 1972), which were the first in Spain.

A third type of reflection, internationally very widespread, debates what these books lying somewhere between art and education are, with great controversy over their relationship with unqualified 'literature' and the dubious educational quality of fantasy and folklore. The discussion about the literary 'essence' of children's literature had very few supporters in the Catalan-speaking area. The fact that books for children had always been envisaged as a vital tool for the success of a cultural project made this discussion pragmatically out of place. And interest in folklore and fantasy experienced a low period in Catalonia. On one hand, the Franco dictatorship extolled a common folklore in service to a single Spanish culture. On the other, the Catalan desire to adopt European cultural airs led to qualms about fantasy characteristic of the rationalist pedagogy that dominated Western countries.

However, the international shift towards fantasy coincided with the arrival of democracy. In the still pre-democratic year 1976, the Catalan publisher Avance published Spain's first translation of The Grammar of Fantasy by Gianni Rodari, and the Catalan- 
speaking area then enthusiastically jumped on board since the desire to keep up European modernity and the recovery of the oral tradition as native culture came together. The work of Gabriel Janer Manila was innovative and a point of reference in this field, and under his expertise the university centre of the Balearic Islands paid special attention to study of folklore, fantasy and children's literature.

\section{The establishment of university research at the turn of the 21 st century}

In the 1980s and 1990s, children's and young adult literature gained ground as an object of academic study. The publisher Pirene prepared the first collection of studies in Spain in Catalan, with its own translations and studies, while education in children's and young adult literature was extended to university degrees, especially education. University departments thus took charge of this new area under construction.

In the late 1990s, Catalan researchers created the first network of university research in Spain, an important fact that reveals a leap in the development of these studies. Titled Thematic Network of the Theory, History and Educational Use of Catalan Children's and Young Adult Literature (1999-2006) and coordinated by Teresa Colomer, it brought together all of the researchers from the University of Alicante, the Autonomous University of Barcelona (UAB), the University of Barcelona (UB), the University of the Balearic Islands (UIB), Rovira i Virgili University, the University of Valencia (UV) and the University of Vic (UVic). It left us with two publications addressing the foundations of these studies.

One deals with the foundation of Catalan literature. El patrimoni de la imaginació: llibres d'ahir per a lectors d'avui (The Heritage of Imagination: Books of Yesterday for Today's Readers) was coordinated by Mònica Baró, Teresa Colomer and Teresa Mañà and published in 2007 in Palma thanks to Gabriel Janer Manila, then director of the Institute of Balearic Studies. As the title indicated, it sought to recover and disseminate the works that make up the Catalan literary tradition.

The other deals with the foundation of Catalan studies. La literatura infantil i juvenil catalana: un segle de canvis (Catalan Children's and Young Adult Literature: a Century of Changes) was coordinated by Teresa Colomer and published in 2002 by the Institute of Education Sciences of the UAB. ${ }^{\mathrm{v}}$ It sought to establish a map of the social and cultural changes that had conditioned the development of production over the 20th century as well as those of the Catalan studies that were specifically aimed at each of these areas. ${ }^{\mathrm{vi}}$

Regarding these centres of interest, the key works of this period can be divided into three groups. The first focuses on the expansion of the studies of folklore and history (with authors like Janer Manila, Valriu and Castillo). The second group is concerned with works that adopted themes and approaches of the literary and artistic studies of the second half of the 
20th century, with the new consideration for the reader, and brings them together with the new attention to the learner of the educational disciplines. The adoption of these perspectives, with the introduction of the Anglo-Saxon influence that outstripped French influence, led to a qualitative jump in the modernization of the studies (Colomer, Duran, Lluch and Mendoza). Other perspectives can be placed in the third group: the ideological perspective (Bassa, Obiols), that connected with the age of the audience (Duran i Ros) and the first existent report in Spain on school libraries (Baró, Mañà and Roig) as an indication of the progress in thematic variation and breadth as well.

\section{Research in the last decade}

Once studies of children's and young adult literature were integrated at universities, their evolution followed the general path of the university system in Western countries. Their most characteristic feature is the configuration of stable research groups: BESCOLAR, on school libraries, led by Teresa Mañà at the UB; FRAC, Receptive Training and Skills Analysis Research Group, long led by Antonio Mendoza and currently headed by Margarida Prats at the UB; GREIB, Research Group on Ethnopoetics in the Balearic Islands, led by Caterina Valriu of the UIB; and GRETEL, Research Group on Literature for Children and Young Adults and Literacy Education led by Teresa Colomer at the UAB.

A second characteristic is the internationalization of the research. It is here that we can affirm that the Catalan-speaking area has been established as a powerful seat of research on the international map. We will mention three aspects:

1. The particularly intense contact between Catalan researchers and other universities and institutions in Spain, Latin America and the EU. By way of example we could highlight participation in international research, such as Gemma Lluch's collaboration with Fundalectura of Colombia on selection criteria, and Teresa Colomer and the GRETEL team's involvement with the universities of Glasgow and Sydney and Columbia University on reception and migratory contexts, which received international awards upon publication.

2. The creation of the European Network of Picturebook Research at the 2007 Symposium of the Autonomous University of Barcelona, organized by Teresa Colomer, Bettina Kümmerling-Meibauer and María Cecilia Silva-Díaz. The symposium brought together the most prestigious picture book specialists in the world, had continuity through biannual symposia (in Glasgow, Tübingen, Stockholm, Gdańsk and in 2017 Padua) and gave way to international publications.

3. Exchanges and attracting researchers to Catalan universities for research placements, completing doctoral theses, etc. To give an illustrative figure, and pardon me for using 
the only one I am familiar with in depth, in this year alone the GRETEL research group has accommodated sixteen visiting researchers from eleven countries on stays varying in duration from weeks to months.

Regarding the fields of interest for this last decade, note should be made, first, of some works of general scope or which delve into the historical lines as well as the research work done through exhibitions, often spurred by anniversaries or commemorations, some of it under the direction of Teresa Duran. Secondly, the works aimed at young readers, especially based on the social concern regarding reading habits and young people's transition to screens. Thirdly, the line of literary analysis and reading reception that has shifted towards interest in digital formats in highly pioneering research. To already familiar names like Colomer, DíazPlaja, Lluch, Manresa, Mendoza, Prats and Valriu we can add the recent research into reception, illustration and digital literature by Amat, Bellorín, Bosch, Ramada, Reyes and Turrión. Consulting the list of articles on Catalan children's and young adult literature honoured with the Aurora Díaz-Plaja Award from the AELLC in fifteen editions led by Pere Martí also gives an indication of which topics have garnered the most attention, such as a third of the winning articles being devoted to Catalan children's poetry.

\section{The training offer}

The international shift of universities towards an undergraduate and graduate structure has encouraged the expansion of the training offer. In the specific case of children's and young adult literature, the Catalan-speaking area has become a powerful world centre for training researchers and professionals from all sectors involved. We can highlight the following achievements:

In the 2004-2005 academic year the online master's programme in Children's and Young Adult Books and Literature was created, organized by the UAB in collaboration with the Banco del Libro of Venezuela and coordinated by Teresa Colomer and María Cecilia Silva-Díaz. With a strong international footprint from the start, its 10 editions have hosted over 400 students from 25 countries, and its faculty team has been made up by over 130 professionals from 20 different countries.

In the 2008-2009 academic year the interuniversity master's programme in School Librarianship and Reading Promotion (UAB-UB) was offered, organized by Mònica Baró, Teresa Mañà and Teresa Colomer. It was the first official master's programme in school librarianship in Spain, continues to be the only one to date and its success has crossed borders in such a way that it has been taken as a model for other training offers and has been entrusted with organizing specific courses by international bodies. 
The offer has continued to grow with the diversified organization of university courses with 10 to 30 academic credits. Among those currently offered we can mention the following in order of longevity: the course in Children's and Teenager's Books: Production, Uses and Reception of the UAB; the virtual diploma in Culture, Reading and Literature for Children and Young Adults of the UV; the diploma in Bookselling of the UB and the Catalan Guild of Booksellers; the course in Children's Books from a Global Perspective of the UAB and the recent course in Prescribed Reading of the UB. We can also add the existence of stable periodic activities like the Summer School of Children's and Young Adult Literature of the UVic and the UCC in collaboration with the Abadia de Montserrat and the courses of the Rosa Sensat Summer School and elsewhere in the region.

Separately we highlight the long Catalan tradition in illustration training, an especially powerful fact in the new context of interest in the image: the master's degree in Illustration and Comic of the ELISAVA School and the UPF; the master's degree in Creative Illustration, which includes the postgraduate courses in Illustration, Digital Illustration and New Media, of the BAU, the UVic and the UCC; the master's degree in Design and Illustration of the UPV; the graduate diploma in Creative Illustration and Visual Communication Techniques of the EINA School and the UAB; the higher vocational training qualifications of the Escola Massana and the UAB, the Escola Llotja of Barcelona and the Escola Illa of Sabadell and the specialisation course in Illustration for Children's and Teenagers' Publications of the EINA School and the UAB.

Children's and young adult literature has also been no stranger to the virtual and open learning movement developed internationally in recent years. The way was paved by the course Choosing Books for Children and Young Adults commissioned by the Open Institute of Catalonia to the GRETEL Group of the UAB, coordinated by Mireia Manresa. ${ }^{\text {vii }}$

We will close the reference to the Catalan training offer with a future project of great reach. For the first time an Erasmus Mundus Joint Master Degree (EMJMD) of children's and young adult literature has been proposed for the EU. The project for the international master Children's Literature, Childhood Culture and Media, coordinated by Evelyn Arizpe of the University of Glasgow, brings together the European universities that have been considered the most active centres of research and training: Aarhus University, the Autonomous University of Barcelona and Tilburg University plus the University of British Columbia in collaboration with another fifty organizations around the world like the International Youth Library in Munich. The UAB is willing to assume the European coordination of the master's programme if Brexit makes Glasgow's coordination impossible. 


\section{Criticism and other institutions}

Although this presentation has been focused on research and training in Catalan children's and young adult literature offered by universities, fortunately "there is life beyond" through a network of professional agencies and organizations that are a hotbed of activity in terms of criticism and dissemination.

We will mention just a few of the very different organizations that foster research and dissemination, beginning with the Institut Ramon Llull, which has organized this encounter and maintains a line of grants for promoting publishers and illustrators abroad; the Rosa Sensat Teachers Association, where groups and initiatives around books converge; ClijCAT, highlighting two interesting studies on the reading habits of children and young adults (2005, 2010); the "puntedu" School Library Programme of the Government of Catalonia, which gave new impetus to school libraries; the Observatory on Libraries, Books and Reading of the UB, which publishes an online yearbook with industry reports of great interest to capture the pulse of the different aspects of children's and young adult books; ${ }^{\text {viii }}$ the Association of Catalan Language Writers (AELLC), which has made it possible to organize five conferences on Catalan children's and young adult literature; the Jordi Sierra i Fabra Foundation, based in Medellin and Barcelona; the Jaume Bofill Foundation, with programmes for literacy research and support; the Children's and Young Adult Literature Documentation Centre located in the Biblioteca Xavier Benguerel of Barcelona and the now defunct journal Ooohéee. Estudis sobre la creació $i$ edició infantil $i$ juvenil of the Balearic Studies Institute, published in three languages. Both the documentation centre and the journal are examples of the attempt to create the necessary infrastructure for research and dissemination.

With regard to specialized criticism, there are long-running journals and significant activity in digital formats. In print, mention should be made of the journal Faristol from ClijCAT, now with a digital version as well, and the journal CLIJ. Cuadernos de literatura infantil y juvenil. The website of the educational administration of Catalonia includes a digital selection from the Children's and Young Adult Literature Seminar of the Rosa Sensat Teachers Association grouped by age, and there is a wide range of specialist websites like the veteran Cornabou with its collection of articles La Saloquia,Llibres al replà, Mascaró de proa and La invitació a la lectura; while Boolino has tried a more familiar and commercial website and the GRETEL group includes monthly recommendations of print and digital works as well as a database that shows the twenty most critically acclaimed works by age group since 2000 from the ongoing analysis of over 15 specialized bibliographical sources.

To close this presentation, I will mention a fact specific to Barcelona but one which is representative of the interest in books, the coordination of efforts in all sectors, openness to the word and the future possibilities we have sought to show in this intervention from the 
sphere at hand: in 2016 Barcelona was named a City of Literature within the UNESCO Creative Cities Network. Children's and young adult books were present in the merits described for the city in its candidacy in an article by Teresa Colomer. The process of active participation of the different sectors involved resulted in both the reporting of our position to explain it to the world and the possibility to dream of more and better abilities. We hope that the opportunity the Bologna Book Fair has today provided us with will also contribute to enabling us to better understand each other and together imagine paths to progress for future generations to access the books and literature that await them.

\section{Bibliografia citada al text o a la presentació | Bibliography citied in the text or in the presentation}

Amat Castells, V. (2016) Aprendre a valorar les lectures literàries. Anàlisi d'una intervenció didàctica a cicle inicial (tesi doctoral inèdita). Universitat Autònoma de Barcelona.

Amo, J.M., i Mendoza Fillola, A. (Eds.) (2015). Redes hipertextuales en el aula. Barcelona: Octaedro.

Arizpe, E., Colomer, T., i Martínez-Roldán, C. (2014). Visual journeys through wordless narratives. An international inquiry with immigrant children and "The Arrival". Londres: Bloomsbury.

Baró, M. (2005). Les edicions infantil i juvenils de l'Editorial Joventut (1923-1969) (tesi doctoral inèdita). Universitat de Barcelona.

Baró, M., Mañà, T., i Roig, A.M. (1990) Les biblioteques a les escoles públiques de Catalunya. Barcelona: Diputació de Barcelona.

Baró, M., Colomer, T., i Mañà, T. (Eds.) (2007). El patrimoni de la imaginació: Llibres d'ahir per a lectors d'avui. Palma: Institut d'Estudis Baleàrics.

Bassa, R. (1994). Literatura infantil catalana i Educació (1939-1985). Palma de Mallorca: UIB-Fundació Barceló.

Bellorín Briceño, B. (2015). De lo universal a lo global: nuevas formas del folklore en los álbumes para niños (tesi doctoral inèdita). Universitat Autònoma de Barcelona.

Bettelheim, B. (1997). Psicoanálisis de los cuentos de hadas. Madrid: Crítica.

Bosch, E. (2015). Estudio del álbum sin palabras (tesi doctoral inèdita). Universitat de Barcelona.

Castillo, M. del. (1997). Grans il lustradors catalans. Barcelona: Barcanova. 
Colomer, T. (2015). Barcelona ciutat literària: literatura infantil i juvenil. Barcelona: Ajuntament de Barcelona.

Colomer, T. (Ed.) (2008). Lectures adolescents. Barcelona: Graó.

Colomer, T. (Ed.) (2002). Siete llaves para valorar las historias infantiles. Madrid: Fundación Germán Sánchez Ruipérez.

Colomer, T. (Ed.) (2002). La literatura infantil i juvenil catalana: un segle de canvis. Barcelona: ICE-Universitat Autònoma de Barcelona.

Colomer, T. (2010). Introducción a la literatura infantil y juvenil actual. Madrid: Síntesis.

Colomer, T. (1998). La formació del lector literari. Barcelona: Barcanova.

Colomer, T., i Fittipaldi, M. (Eds.) (2012). La literatura que acoge: inmigración y lectura de álbumes. Barcelona-Caracas: Banco del Libro.

Colomer, T., Kümmerling-Meibauer, B., i Silva-Díaz, M. C. (Eds.) (2010). Cruce de miradas: nuevas aproximaciones al libro álbum. Barcelona: Banco del Libro.

Colomer, T., Kümmerling-Meibauer, B., i Silva-Díaz, M. C. (Eds.) (2010). New Directions in Picturebook Research. Nova York, Londres: Routledge.

Díaz-Plaja, A. (2011). Escrito y leído en femenino: novelas para niñas. Análisis y valoración en su contexto. Cuenca: Publicaciones de la UCLM.

Duran, T. (2007) Allbums i altres lectures. Barcelona: Rosa Sensat.

Duran, T., i Ros, R. (1996). Primeres literatures: llegir abans de saber llegir. Barcelona: Pirene.

Jan, G. (1988). El poder de los cuentos. Barcelona: Pirene.

Janer Manila, G. (1982). Cultura popular i ecologia del llenguatge. Barcelona: CEAC.

Janer Manila, G. (1989). Pedagogia de la imaginació poètica. Barcelona: Aliorna.

Larreula, E. (1985). Les revistes infantils catalanes de 1939 ençà. Barcelona: Ed.62.

Lluch, G. (1998). El lector model en la narrativa per a infants $i$ joves. València: Publicacions de la Universitat de València.

Lluch, G. (Ed.) (2000). De la narrativa oral a la literatura per a infants. Invenció d'una tradició literària. Alzira: Bromera.

Lluch, G. (2003). Análisis de narrativas infantiles y juveniles. Cuenca: UCLM.

Lluch, G. (2010). Cómo seleccionar libros para niños y jóvenes. Los comités de valoración en las bibliotecas escolares y públicas. Gijón: Trea.

Lluch, G., i Valriu, C. (2013). La literatura per a infants $i$ joves en català anàlisi, gèneres $i$ història. Alzira: Bromera i Institut Interuniversitari de Filologia Valenciana. 
Manresa, M. (2013). L’univers lector adolescent. Dels hàbits de lectura a la intervenció educativa. Barcelona: Rosa Sensat.

Manresa, M., i Real, N. (Eds.) (2015). Digital literature for children: Texts, readers and educational practices. Brusel·les: Peter Lang.

Manresa, M. (Ed.) i Equip GRETEL (s.d). Triar llibres per a infants. IOC de Catalunya.

Mendoza Fillola, A. (2007). Tú lector. Barcelona: Octaedro.

Mendoza Fillola, A. (Ed.) (2008). Textos entre textos. Las conexiones textuales en la formación del lector. Barcelona: Horsori.

Obiols, N. (2004). Mirando cuentos: lo visible y lo invisible en las ilustraciones de literatura infantil. Barcelona: Alertes.

Prats Ripoll, M. (2009). La poesia per a infants. Estat de la qüestió en llengua catalana. Caplletra. Revista Internacional de Filologia, 46, 149-182.

Ramada Prieto, L. (2017). Esto no va de libros. Literatura infantil y juvenil digital y educación literaria (tesi doctoral inèdita). Universitat Autònoma de Barcelona.

Reyes López, L. (2015). La formació literària a primària. Impacte d'una intervenció educativa en l'evolució de respostes lectores (tesi doctoral inèdita). Universitat Autònoma de Barcelona.

Rodari, G. (1977). Gramática de la fantasía. Introducción al arte de inventar historias. Barcelona: Avance.

Rovira, T. (1988). La literatura infantil i juvenil. A M. De Riquer, A. Comas, i J. Molas (Eds.), Història de la literatura catalana v. XI (pp. 421-471). Barcelona: Ariel.

Rovira, T. (1968). Libros infantiles en catalán. A B. Hürlimann (Ed.), Tres siglos de literatura infantil europea (pp. 315-331). Barcelona: Juventud.

Rovira, T. (1976). Noucentisme i llibre infantil: influència del Noucentisme sobre la producció i difusió del llibre per a infants (tesi de llicenciatura inèdita). Universitat Autònoma de Barcelona.

Rovira, T., i Ribé, C. (1972). Bibliografía histórica del libro infantil en catalán. Madrid: ANABAD.

Samaranch, J. (1978). L'editorial Muntañola i les seves publicacions (tesi de llicenciatura inèdita). Universitat de Barcelona.

Seminari de bibliografia infantil de Rosa Sensat (1977). Quins llibres han de llegir els nens?. Barcelona: Publicacions de Rosa Sensat.

Turrión, C. (2014). Narrativa infantil y juvenil digital. ¿Qué ofrecen las nuevas formas al lector literario? (tesi doctoral inèdita). Universitat Autònoma de Barcelona. 
Valriu, C. (1994). Història de la literatura infantil i juvenil catalana. Barcelona: Pirene.

Valriu, C. (1998). La influencia de les rondalles en la literatura infantil i juvenil actual. Palma: Editorial Moll.

Ventura, N. (1970). Llibres en català 1939-1970 (tesi de llicenciatura inèdita). Universitat de Barcelona.

\footnotetext{
${ }^{i}$ En són autors: Ramon Bassa, Mònica Baró, Teresa Colomer, Montserrat Correig, Ana Díaz-Plaja, Teresa Duran, Anna Gassol, Maria Gonzàlez, Enric Larreula, Gemma Lluch, Gabriel Janer Manila, Teresa Mañà, Antonio Mendoza, Àngels Ollé, Rosa M. Postigo, Margarida Prats, Caterina Valriu i Núria Vilà.

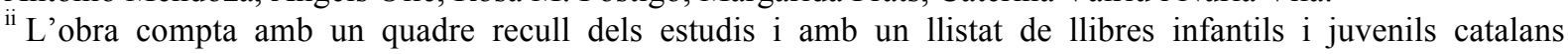
recomanats.

iii Vegeu: http://miniops.ioc.cat/10/

iv També faciliten el seguiment anual de la producció els articles panoràmics publicats als mitjans per M.Teresa Blanch, Joan Anton Fluixà, Joan Portell o Teresa Mañà.

${ }^{v}$ Its authors were Ramon Bassa, Mònica Baró, Teresa Colomer, Montserrat Correig, Ana Díaz-Plaja, Teresa Duran, Anna Gassol, Maria Gonzàlez, Enric Larreula, Gemma Lluch, Gabriel Janer Manila, Teresa Mañà, Antonio Mendoza, Àngels Ollé, Rosa Maria Postigo, Margarida Prats, Caterina Valriu and Núria Vilà.

${ }^{\mathrm{vi}}$ The work features a summary table of the studies and a list of recommended Catalan children's and young adult books.

vii See: http://miniops.ioc.cat/10/

viii It also provides annual following of the production of overview articles published in the media by Maria Teresa Blanch, Joan Anton Fluixà, Joan Portell and Teresa Mañà.
}

Informació sobre l'autora:

Teresa Colomer és Catedràtica de didàctica de la literatura de la Universitat Autònoma de Barcelona. Dirigeix el grup de recerca GRETEL sobre les relacions entre lectura, literatura infantil i juvenil actual i educació literària a l'escola obligatòria. És autora de més de 250 publicacions sobre aquests temes.

Email: teresa.colomer@uab.cat

Per citar aquest article:

Colomer, T. (2018). Recerca i formació de professionals en el camp de la literatura infantil i juvenil $\mid$ Research and training of professionals in the field of children's and young adult literature. Bellaterra Journal of Teaching \& Learning Language \& Literature, 11(1), 9-26. DOI: http://doi.org/10.5565/rev/jt13.762 